\title{
NEGATIVE OR POSITIVE UNDERSTANDING OF FREEDOM
}

\author{
Pavel Angelov ANGELOV \\ G. S. Rakovski National Defence College, Sofia, Bulgaria \\ pavanga@gmail.com
}

\begin{abstract}
In recent decades, the question of freedom in market society and responsibility in the behavior of market players has been raised again. Usually, in the public sphere, the thesis is stressed that the state is the main reason for restricting the freedom of the market subjects. In this article, the perception of freedom as negative or positive is stated and analysed; freedom is accepted, understood and refers to every subject, member of society and participant in the market game; subject who in his/her free actions does not subdue and does not harm others and the rest. In their complex life existence ordinary people seem to be between Scylla and Charybdis of the state and the powerful national and transnational market subjects.
\end{abstract}

KEYWORDS: negative freedom, positive freedom

\section{Introduction}

Today with neo-liberalism in a national and supranational aspect, the ongoing economic globalisation practically affirms the insistent thesis that the state is a main reason for restricting the freedom of the market subjects. Along with this, we have to rely on the good old 'invisible hand' - the market, as the only suitable tool (although invisible, intangible) to guarantee more freedom for the market subjects in the conditions of today's Western postmodern capitalism. Thus, with faithful conviction, it is imposed on society that there is a simple one-line dependence, namely, that more market competition (reflection of social Darwinism) is equal to more economic freedom.

\section{Definitions of Freedom}

But an inquisitive reader could ask himself/herself and consider whether only the state is capable of restricting the freedom, the security of the economic and civil subjects, different communities and society. For example, the big market players, monopolies, oligopolies, corporations, transnational companies can also dominate the rest of the market subjects, both in terms of the existing common demand and common supply; can also dominate the different communities and the civil society. This is no longer a rhetorical question, but a reality both the state and the powerful market players are able to restrict the freedom of the rest of the market subjects, the weaker market subjects and the subjects of the civil society.

But unlike state domination, the power exercised by the big market players could not be with administrative, regulatory, political, moral regulators and ways of influencing people's behavior and restricting their freedom but with market, economic, monetary regulators; controlling the behaviour of subjects by deliberate impact on the demand and supply of goods and services; intrusion of certain products 
and forms of consumption; the formation of such a distribution of income which leads to the 'excessive opening of the scissors' between the so-called "capital income" compared to "labour income"; varied means of indirect social coercion and impacts on people, exercised by monopolistic business subjects, et cetera. The varied manifestations of economic coercion on the fundamentally separately weaker economic individual subjects (a side in labour legal relationships as mercenaries) adversely affect the foreign field of free action. But, along with this, the owners of a hired work force participate in the common demand in which there are also threats for their being. They are located between Scylla and Charybdis (in ancient Greek mythology mythical sea monsters that lurk the ship of Odysseus and his companions in the narrow strait on their journey home). The economically weak individual market subjects are located between the state and the strong national and transnational economic players. Of course, they can suffer from Scylla or Charybdis; but a worse scenario is possible for the individual subjects travelling in the market sea. When Scylla and Charybdis enter into an intimate relationship, then it is possible that the rest of the economic and social subjects are doubly threatened by the mutually beneficial communication between these today's monsters of a different power.

\subsection{Negative Freedom}

Ludwig von Mises (2008) in his masterpiece Human Action reflects on the alternative "automatic forces" or "conscious planning", or in other words - the free market as an alternative to the state. He asks himself the question - who is actually planning? For him the alternative is individual freedom versus "government's omnipotence". Consequently, the freedom of one type of subject is at the expense of, or restricts, the freedom of the other, namely, the government's omnipotence is reproached and must retreat in favor of the liberty of the so-called Ludwig von Mises "ordinary man". By the way, in this aspect, for example, we can ask ourselves here: what is the nature, the structure, the composition of this "ordinary man", and we can try to recognize $\mathrm{him} / \mathrm{her}$. Is the "ordinary man" made up of those ordinary people who can, for example, walk along the streets or are they any other?

Obviously, Ludwig von Mises understands freedom in a way that is typical of liberalism - as negative freedom. For example, he states: we can define freedom as a state of affairs in which the choice of the individual is not restricted by government coercion beyond the threshold to which praxeological law restricts this choice of the individual anyway (Mizes, 2008). And one more definition of the freedom of man which is related to the market economy: we define freedom as the state of the individual within the frames of the market economy. He is free in the sense that laws and government do not force him to renounce his autonomy and selfdetermination to a degree greater than the restrictions of the praxeological law (Mizes, 2008).

Negative freedom is perceived as a lack of certain external constraints for the actions of economic people and social communities (Hayek, 1960). Here, it is appropriate to recall the well-known essay On Liberty by John Stewart Mill (Mill, 1999). Mill's main assertion is that man's freedom is based on the fact is that it is man who is the sovereign of himself, his own body, mind. In this sense, according to Mill, the components of freedom are:

First: The freedom of thought and emotion. This includes the freedom of an opinion and the freedom to publish our opinion, known as the freedom of speech.

Second: The freedom of "tastes and pursuits", even if they are deemed 'immoral' by the other members of society (provided they do not harm others). 
Third: The freedom "to unite" or the freedom to self-organise people.

For Mill, long before Mises, the tyranny of the government or the majority must be controlled by the freedom of the citizens. An important point is that according to this British philosopher and political economist (and member of a liberal party), the tyranny of the majority is worse than the tyranny of the government because the tyranny of the majority is not politically restricted. Together with this, for Mill, there is one limiting factor for freedom - the harm that can happen from the lack of external restrictions on the part of the state in the form of physical or moral pressure on others. In this sense, in his view, it is permissible and legitimate to exert power over an individual, a member of a civilized community, contrary to their will, only to prevent harm to others. Of course, it is important here to define the notion of harm that can be understood differently depending on certain interests.

The liberal understanding of freedom as negative freedom, absence or lack of restrictions upon, for example, the freedom of speech, the freedom of a personal life, freedom of mobility et cetera is widely accepted and implanted in the western public consciousness. But therefore I think that with serious justification along with Mises recommendation - let the ordinary man choose and act and do not force him / her obey a dictator (Mizes, 2008), it should be added (according to Mill's advice) if he/ she does not cause any physical or moral harm to others (or the rest). Doesn't the right of the individual subjects also imply the corresponding responsibility for the results of their own actions? This is an important projection of the freedom of the rest of the subjects, communities, societies.

\subsection{Positive Freedom}

On the other hand, freedom can be perceived as positive freedom (Gibbs, 1976) in the sense that it is possible for the social subjects to act as far as they have knowledge of the causes but also of the consequences of their actions. It is knowledge that makes man free; in other words, freedom is realised in the social reality in accordance with the level of knowledge of human individuals. Consequently, freedom understood as positive can be a prerequisite for setting and achieving certain desired goals, realisation of chances; an own spiritual possession of the means (knowledge) for the realisation of intentions of the members of society. Today it is hardly enough to understand freedom as 'by' (something that restricts us), but we also need freedom in the sense of "for" realised possibilities and responsibilities.

In today's market society the preservation and development of the human, social relationships and interactions can be realised in the context of freedom if every member of society is protected from the tyranny of stronger, better informed, smarter personalities including formal organizations (in business and public sector) or institutions and, of course, the government. Collaboration and peace such as the absence of an eternal and irreconcilable struggle of everybody with everybody can be achieved in the existence of a particular social monopoly for applying coercion. In this sense a reasonable question arises asked by the American economist Richard Rahn, one of the ideologists of Reaganomics, supporter of the restricted government and economic liberalism: Do we need restrictions on our freedoms in order to ensure freedom? If we consider the primary function of the state to preserve freedom and protect the individual and property, then we tacitly acknowledge the need of some police power, including defense. Police and troops cost money, which implies taxes, and the more each of them grows the more taxes and, therefore, less freedom is needed. Too much police and too many laws endanger freedom; too little and few of them means that freedom 
may not be protected. To live freely implies to live dangerously (Rahn, 2011). Obviously, for each individual case, regulations are implemented within a framework of certain rules that are different from the law of the "jungle" or "social Darwinism" and are opposed to the jungle (social Darwinism). But this social monopoly on coercion (must be) subordinated to the sovereign or the civil society and to act solely in its interest only if constant and profound civil control is exercised over the government.

This is why we have reasons to understand freedom of man in the context of today's so-called market society as a set of possible and real autonomous, independent and/or solidarity actions unlimited by law, government, other market subjects, corporate subjects and formal organizations. Consequently, through meaningful human actions, personal interests can be combined with public interests and goals. This is possible if we accept and acknowledge that it is precisely the internal limiting of human freedom which is decisive, a realised by man necessity in comparison with the external constraints of the state and monopolistic market subjects and other formal organizations.

From the viewpoint of the separate human individual, freedom implies an activity independent from external pressure and coercion by the individual members of society. But from a more general point of view of the socium, the free action of individuals implies their mutual recognition and real practice of equivalence in order to avoid the dominance of the stronger over the weaker. Together with this, freedom can be conceived in the two above-mentioned meanings: freedom as an opportunity for action or freedom as a lack of restriction on action, or in other words as "positive and negative liberty" in Isaih Berlin terms (Prodanov, 2011).

\section{Conclusion}

Dear inquisitive reader, here we are trying to look at freedom because of its fundamental importance in contemporary capitalist society in which the subjects basically have two kinds of freedom. In economic terms, on the one hand, people are free to make a choice by hiring somebody else's work force and accept the role of a subject of capital. On the other hand, every man is free to make the choice of letting others use his/her work force under certain conditions. Consequently, it is essential that under the conditions of capitalism people can make a choice in which two alternatives of free action are basically realised. However, the realisation of the choice is permissible provided that one is able to distance himself/herself from the circumstances around him so that he/she one can observe and analyse the possibilities and dangers of the socioeconomic environment. The full participation of the market subjects in the economic or market game is not instinctive and biological as in the "jungle", but is socially motivated and conscious, which necessitates constantly meaningful behavior of the people.

Practicing a social, economic choice pulls us out of the tracks of animal instincts that are only related to the satisfaction of their own biological needs. People have a clear awareness of their own limitations and extremes, have a sense of time, and can therefore explore their past (their history) and look ahead to the future. In modern conditions, along with the development of democracy in social relations and liberalisation in the economy, it is logical and natural for freedom to be accepted, spread and to concern every subject, member of society and participant in the market game. Because of course:

$\checkmark$ freedom is not only for those who made their choice to hire people (employers), but also for others who chose to be hired (employees); 
freedom is not only in the sense that employees are free to simply to let their workforce be used by a particular employer within the framework of a given formal organization;

$\checkmark$ but as well as those who hire (employers) and participate in a competitive (in a certain sense solidarity) market environment, also the subjects who let their workforce be used (employees) have free will and have the right to autonomous actions in their own interest; employees participate not only in the market game in specific labour and legal relations in a formal organisation, but also outside it in a large scale socioeconomic market game (regional, national, integrational, globalising) or in the context of a given market society with its characteristic capitalist culture. Moreover, outside the economic, market context both main types of subjects in a particular way participate in the political play, in social relations, in civil society, in human development.

\section{REFERENCES}

Gibbs, B. (1976). Freedom and Liberation, London: Chatto and Windus. Paul.

von Hayek, F. A. (1960). The Constitution of Liberty, London: Routledge and Kegan

Mill, J. S. (1999). On Liberty, available at: http://www.bartleby.com/130/.

von Mizes, L. (2008). Choveshkoto deystvie, Sofia: Izd. Kashta MaK.

Prodanov, V. (2011). Legitimatsiya na prehoda kam vtoriya balgarski kapitakizam. Ideologicheski mitove, Novo Vreme, broi 12.

Rahn, R. W. (2011), Thoughts on liberty, The Washington Times. 